\title{
Adjustment or Structural Change in Crisis Management Policy of Tanzania
}

\author{
By Thomas J. Heinrich
}

There is no doubt: From the end of 1978 onwards, Tanzania has slid into a deep economic crisis, ${ }^{1}$ which is meanwhile threatening to erode the whole social fabric and political system alike. Her trade balance became extremely negative while at the same time the international aid disbursements grew to more than half of Tanzania's development budget, thus causing high interest payments. This resulted in an urgent shortage of foreign currency.

The break within her brief 23 years of independent development came abruptly after a short period of relative economic prosperity in the mid-seventies. To that situation the government reacted with an ad hoc programme for $1981^{2}$ and with a more elaborated Three Year Plan for the period 1982/83 to 1984/85: The so-called "Structural Adjustment Programme". ${ }^{3}$ Within this timespan it was hoped, the economy could recover on a wave of world-wide economic upsurge.

The "Structural Adjustment Programme" (SAP), is to be the focus of my comments on crisis management in Tanzania.

\section{Causes and Repercussions of an Economic Crisis}

Basic divergence of opinions exists, firstly, on the causes of the current economic crisis and, secondly, on the range of policy options open to the Tanzanian government to handle the crisis.

In the view of conservatives, it is mainly internal causes' that are held responsible for the crisis in Tanzania. ${ }^{4}$ They pinpoint, above all, the social policies of the government as the chief-culprit of the economic crisis, neglecting the fact that Tanzania is only part of the general crisis that has afflicted sub-Saharan countries, whereas the financial breakdown of advanced developing countries like Brazil and Mexico with even more western inclinations in their development strategy, is not even mentioned. And these biased politicians neglect that the debt service ratio of Tanzania is less than that of the African countries in average.

For basic data see: Statistisches Bundesamt Wiesbaden, Länderkurzbericht Tanzania, 1980.

United Rep. Of Tanzania "The National Economic Survival Programme", DSM 1982.

United Rep. Of Tanzania "Structural Adjustment Programme For Tanzania", DSM 1982.

4 Hans-Peter Repnik "Sollen die Menschen für die Fehler ihrer Führer büßen?", one page background article in "Frankfurter Allgemeine Zeitung", 14. 9. 1983; further the more blunt article of Wolfgang Höpker in Afrika-Post, 11/1983. 
Such explanatory attempts to grapple with the world-wide crisis of developing as well as developed countries have their broader political implications:

1. they blur the disastrous effects of the discriminatory international economic order on countries like Tanzania. ${ }^{5}$

2. they pave the way for a discriminating link between political good conduct of the government and provision of foreign aid for them. ${ }^{6}$

In fact, the reasons behind Tanzania's crisis - to name but the most important ones - were basically determined externally by the unfavourable terms of trade of the world market, the second oil price hike (1978-80), a devastating drought and, last but not least, the Ugandan war, that put a burden of approxemately 4 billion TSHs (1 billion DM) on the national budget. Secondly, and broadly resulting from that, there was an accelerating deterioration of the performance of governmental bodies and so-called parastatals, and a general decline in political ethics. ${ }^{7}$

Table 1

Development of Foreign Trade (in mio. Tanz. Shilling)

\begin{tabular}{|l|r|r|r|r|r|}
\hline & 1965 & 1970 & 1975 & 1980 & 1981 \\
\cline { 2 - 6 } Exports & 1476 & 1797 & 2764 & 4166 & 4807 \\
Imports & 1410 & 2274 & 5709 & 10308 & 10047 \\
Balance & 66 & -477 & -2945 & -6142 & -5240 \\
\hline
\end{tabular}

Source: Bank of Tanzania, see footnote 19

Remark: $100 /-$ TSHs $=12.2$ US in 1980

Due to this economic crisis, Tanzania's great sociopolitical achievements are now at stake: political stability; social improvements in rural areas, based on the villagisation programme as a prerequisite; universal primary education; the extension of water and health facilities to urban and rural areas.

5 World Bank, "Economic Memorandum on Tanzania", 1981, p. 14.

6 This is most clearly shown by the present attitude of the US-government and its decision, at the end of 1983, to take the voting pattern of developing countries in the United Nations as an indicator for the assigument of development aid. Concerning the foreign aid policy of the FRG see e. g. Frankfurter Rundschau, 4. 1. 1984.

7 In this context see: World Bank "Accelerated Development in Sub-Saharan Af rika" (Washington 1981); this book, not surprisingly, puts the internal causes on top and the adverse world market conditions second. For an opposite view take: The United Rep. Of Tanzania "The National Economic Survival Programme", DSM 1982. 
In addition, a situation has emerged that lays the existing infrastructural facilities idle for lack of resources to make them work; e. g. transport, personnel for schools and dispensaries not being sufficiently trained and rewarded to commit themselves to their duties, teaching materials and health care supplies.

Improvements achieved in Tanzania's social infrastructure are not to be disputed - even not by conservative critics. However, the economic growth needed as a solid foundation for the maintenance and functioning of those facilities remains crippled, thus, directly and indirectly, leaving vast development potentials in the villages and towns untapped.

\section{Consequences of the crisis: Is the "Tanzanian Model " at stake?}

In this context, it is the intention of this article to look into some aspects of the present constraints which define the range of policies open to the Tanzanian government to pursue some sort of self reliant development. To be sure, political constraints result from a weak economic position. But how are these constraints structured nationally and internationally? Which international organizations do exert meaningful pressures on Tanzania and of what kind? To what extent does the weakened national position itself lessen the range of options for Ujamaa socialism? Answers to these questions will throw some light on the growing general dependence of Tanzania on industrialized countries. The whole issue of forced structural adjustment of national politics came about when Tanzania had to enter negotiations with the International Monetary Fund (IMF), to solve her severe balance-of-payments deficit. These highly controversial negotiations commenced at the end of the seventies. Moreover, the World Bank as the main commercial source for international aid put pressure on Tanzania to adjust its national policies. ${ }^{8}$

Table 2

\begin{tabular}{|l|r|}
\hline \multicolumn{2}{|l|}{$\begin{array}{l}\text { Balance-of-Payments } \\
\text { (in mio. TSHs) }\end{array}$} \\
\hline 1970 & 456 \\
1975 & 313 \\
1976 & 915 \\
1977 & 1954 \\
1978 & 287 \\
1979 & 287 \\
1980 & -20 \\
1981 & -15 \\
\hline
\end{tabular}

Source: Bank of Tanzania, see footnote 19

8 World Bank, "Economic Memorandum on Tanzania", Washington D.C., 1981 (B), t o the contents see below. 
The "Structural Adjustment Programme" - at present the aquivalent to the National Development Programme of Tanzania - has to be seen as a "compromise" between those external pressures from financing agencies and the endeavour to safequard the social achievements of the past.

Three selected topics may guide the comments on the development strategies of Tanzania in this situation of national dependence.

1. Does Tanzania have anything to loose under the pressure of adverse interests of the World Bank group? Or, in other words, does the "Tanzanian Model", which is at stake, still consist of more than the achievements mentioned above? Has this country still got the freedom of options to defend or even develop the "Tanzanian Model "?

2. How is the "Structural Adjustment Programme" to be assessed in this context?

3. Is it still realistic to pursue the aim of Ujamaa Socialism under the prevailing conditions of poverty, underdevelopment, and resulting national dependence?

To answer these questions it might be useful to recall the basic elements of the Tanzanian Model. Following the guidelines of the "Arusha Declaration" of 1967, three objectives for national development are more or less relevant today: Ujamaa production communities, social equality for all people as well as an economic balance between urban and rural areas, and national self-reliance.

Ujamaa is still being used in the rethoric of politicians today: The SAP promises a "movement towards socialist forms of agricultural organisations", but now as a "longer term objective" ${ }^{9}$ Times have long passed since, in the mid-seventies, the Daily News monthly announced the most recent record of registered Ujamaa Villages (about 7500 at that time). The causes for the collapse of the Ujamaa Vijijini-concept are, of course, both external and internal, thus mirroring the general situation of the nation. Yet, in this case 'kulakisation', bureaucratisation, ${ }^{10}$ and alienation of the traditional peasant mode of production ${ }^{11}$ - internal causes of the decline - are the dominant factors, and World Bank infiltration were only of secondary importance. ${ }^{12}$ However, the idea of communal production was revitalized in 1982 with a new attempt to boost cooperatives. ${ }^{13}$

As to the objective of equality, remarkable progress has been made at least as far as the official income distribution is concerned. The ratio of top to lowest salaries was reduced between 1962 and 1975 from $50: 1$ to about $9: 1 .{ }^{14}$ Additionally, the national programme of IUniversal Primary Education has spread schools to all villages and the policy of clean water to all people, brought remarkable progress to the people upcountry.

9 United Rep. Of Tan., SAP, p. 16.

10 M.v. Freyhold, "Ujamaa Villages in Tanzania", London 1979, p. $116 \mathrm{ff}$.

11 G. Hyden, "Beyond Ujamaa in Tanzania", London 1980, p. 117.

$12 M . v$. Freyhold, ibid., chapter 6.

13 United Rep. Of Tan., "Cooperative Societies Act", 1982. This act would deserve further separate attention, since it is strongly influenced in its legal structure by the intention of the central state to have strict direct control over them.

14 J. K. Nyerere, "The Arusha Declaration Ten Years After", DSM 1977, p. 16. R. Green in Pratt/Mwansasu "Towards Socialism in Tanzania", Toronto 1979, p. 27. 
On the other hand, despite equalizing the social and economic potentials of the different national regions, the predominance of a few towns persists. Contrary to the declared aim of spatial deconcentration, this uneven structure was even supported by allocative decisions - witnessed in the "Third National Five Year Plan" (1976-1981), where a big portion of the development budget had been earmarked for Tanzania's primate city, Dar es Salaam. ${ }^{15}$

Additionally, the tax- and price policy related to agricultural products still discriminates against the peasant in rural areas. ${ }^{16}$

Self-reliance as the primary general objective is still tenaciously defended. In fact, the national identity in peripheral sectors like culture, science and foreign policy is admirably kept up, compared to other African countries. In key areas of development politics such as financing and project implementation, however, Tanzania is highly dependent on foreign aid. Consequently, the donors' preferences determined to a growing extent Tanzania's priorities in terms of investment and programmes, as the SAP concedes. ${ }^{17}$

\section{Background to SAP: Pressures from the World Bank Group}

In this setting of structural national dependence - a dwindling foreign currency fundament and political pressures from World Bank and IMF - Tanzania had to undergo a major adjustment of her politics. ${ }^{18}$ Highly controversial negotiations between Tanzania and IMF started in 1979, in the course of which the Finance Minister Mtei was toppled. As a result of these negotiations the SAP was adopted by the Tanzanian government in 1982. ${ }^{19}$ However, negotiations with IMF for a finance agreement are continuing up to the present.

The IMF and IBRD ${ }^{20}$ as parts of the World Bank Group had made coercive recommendations, having used all the levers at their disposal.

The IMF (as well as the IBRD) as the only source capable to alleviate the negative balance-of-payments of Tanzania first of all demanded a drastic devaluation of the Tanzanian Shilling by $60 \%$ which was admittedly highly overvalued. ${ }^{21}$ Inevitably, such a drastic devaluation must severely hit the urban poor because of higher prices for imported and nationally produced staple food.

Also, the IMF postulated:

15 United Rep. Of Tanzania, "Third National Five Year Plan", Vol. II., p. 108; Vol. I, p. 10.

16 World Bank, "Accelerated Development of Sub Saharan Africa", Washington 1981 (A), p. 26.

17 United Rep. Of Tan., SAP (1982), p. 52; World Bank 1981 (A), p. 8, 32.

18 Along with other countries in Africa.

19 For more details on the history of these negotiations see $R$. Hofmeier, who took part as an independent advisor: "Tanzania - 'Entwicklungsmodell oder Entwicklungsbankrott?», in Deutsches Ubersee-Institut, Jahrbuch Dritte Welt, Bd. 1, 1983, esp. p. 216 f.

20 IBRD = International Bank For Reconstruction and Development or World Bank.

21 Tanzania devaluated 1983 by $20 \%$, after devaluations in 1979 and 1982. 
2. the suspension of the subsidizing of staple food, (maize is essential for the urban poor)

3. the suspension of the government price control system

4. a freeze on government salaries. ${ }^{22}$

5. a reduction of the deficit in the national budget

6. a reduction of state borrowing from the National Bank and

7. a general reduction of central government interventions in the economy, and the encouragement of private enterprise instead.

In sum, this programme was to solve the financial crisis at the expense of the rural and urban poor, it would mean a fundamental attack on Ujamaa Socialism in general and be a decisive blow to its policy of equality in particular.

The $I B R D$ as the main source for foreign aid, and in that the pacemaker for all potential donor countries, demanded:

1. the (re-)integration of subsistence peasants into the market economy by paying better prices for agricultural primary goods and lessening the burden of taxes and duties on them. The aim of this policy was to make the peasants produce not only for the national but also the world market. ${ }^{23}$

2. a rehabiliation programme for competitive industrial assets which are able to push into the world market. Within the national market, these industries should be compelled to stand up to international competition. By strengthening selected industries it is hoped to diminish underutilization of existing capacities, to lift the export rate and thus earn more foreign currency. ${ }^{24}$

3. The industry-related strategy of a more competitive production implies the choice of most suitable places for trade-bound production, i. e. the location of industries in port cities such as Dar es Salaam. This line of the World Bank philosophy is re-inforced by the proposal to abandon the fixed price policy which tried (though, with limited success) to make goods available at equal prices all over the country. ${ }^{25}$ Since such 'recommendations undermine the social aspirations of the Ujamaa concept, a clash over these topics was inevitable.

4. Underlying all this is a constant pressure for more effectiveness, less public costs and spending for services, fewer overhead costs, better planning, and better maintenance of existing failities as e. g. roads, industrial assets, implemented programmes. ${ }^{26}$

These selected remedies' of IMF and IBRD show rather lucidly what is at stake in Tanzania and from which way the wind is blowing on someone sitting in a shack and formulating a national emergency programme. Structural adjustment as spelt out by the World Bank group means, first of all, integration into the world market; secondly,

22 R. Hofmeier, op. cit., p. 217.

23 World Bank, 1981 (A), p. 26 and World Bank, $1981^{\circ}$ (B), p. 21 ff.

24 World Bank, 1981 (B), p. 50, 93.

25 World Bank, 1981 (B), p. 68 ff.

26 World Bank, 1981 (B), p. 32, 24, 39, 59; World Bank, 1981 (A), p. 34 f. 
transforming the mixed economy into a market economy which is competitive at home and abroad; thirdly, doing this at the expense of mainly the urban poor.

Even if one accepts the social costs of these remedies, it is extremely doubtful, whether or not this economic strategy will work out at all. It can hardly be expected that the weak and highly ineffective Tanzanian industry ${ }^{27}$ will manage to enter the closed markets of the industrialized countries. ${ }^{28}$

\section{Three Theses to the Structural Adjustment Programme}

Before looking into the details of the SAP, three theses may be put forward to check them against the programme.

1. In the near future, it will likely not be possible for Tanzania to opt for, and implement, more of the Ujamaa programme as defined above. To that the unbalanced economy, the pressure of the World Bank group and the technocratic wing within the government will pose an unsurmountable stumbling block. The opposite option for more free competition and even deeper integration into the world market would presumably lead to conflicts with the state party (Chama Cha Mapinduzi), which has been superior to the government in the power structure since 1975. Additionally, this would cause severe tensions among the urban poor, ${ }^{29}$ at least during the time period before the country has become an integrated (though peripheral) part of the western industrialized countries. In conclusion, Tanzania is condemned to a muddling through as far as the political programme is concerned: no structural change (coup d' etat excepted).

2. Under the high level of programmatic politics remains a fairly significant level of action: the selection and design of projects. Up to now Tanzania has the option of influencing the form of their projects. The design of big projects like the Mufindi paper mill in Iringa or the fertilizer factory in Tanga ${ }^{30}$ are decisive in determining which way the country goes. In the field of project design the Tanzanian government does not seem to take enough care in its choice. ${ }^{31}$

3. The move towards Ujamaa requires an altered national infrastructure as a prerequisite. To make Ujamaa villages meaningful, a rural road network would be necessary. To decentralize industries into growth poles, a reliable power supply would be needed. Under the prevailing conditions of poverty from independence until today,

27 The actual use of its capacity lies around $20 \%$.

28 In this context see: Hartmut Brandt in Schriftenreihe des DIE, Vol. 71, Berlin 1982, p. 164 ff.; Thomas Fues "Der IWF verschärft seine Kreditbedingungen" in epd 20/21/1983, p. 7 f.

29 At least $60 \%$ of Dar es Salaam population with 1.3 mio inhabitants live at the margin to absolute poverty. Tensions would, in the main, not arise from political motives, but would be due to their living conditions getting even worse.

30 See "Blätter des iz3w", Nr. 60, 1977, p. 7 ff.

31 The author is trying to analyze this in the case of urban planning in Dar es Salaam; PhD forthcoming. 
Tanzania has not managed to produce sufficient national surplus to create these prerequisites. The colonial economic and spatial seeting persists. Without the econimic surplus at hand, the political intentions of Ujamaa, self reliance, and (social and spatial) equality are tantamount to a phantom. This explains the widely known gaps between long term plans, programmes and their implementation in Tanzania.

\section{The Structural Adjustment Programme 1982/3-1984/5}

The SAP has certainly been prepared under the restraints of time and manpower. Nevertheless, it intended - with the help of an international advisory group - to compromise on the above outlined contrversial points of view. Its 54 pages range from longer term objectives to programmes of longer term and immediate action. They are to be considered separately.

Generally speaking, the SAP tries to straddle. It aims at increasing productivity, alleviating the foreign exchange scarcity, and at cutbacks in the government budget, but also at maintaining the social achievements of equality. One hopes to achieve the productivity-related objectives with the following instruments: an austerity policy as to implementing projects, more self-reliance in all sectors, more efficiency and more export.

To avoid the impression of lip-service, the SAP came up with drastic proposals for immediate action: The closure of ineffective enterprises (which in total average are producing at about 20 per cent of their capacity), the postponement of new development projects and the consolidation of existing sound assets and projects. In order to make the industrial machinery run again, high inputs in this sector are necessary, which inevitably incurr foreign exchange. In the opinion of SAP these resources for recurrent use make "substantial drawings and credits from the IMF and the World Bank" necessary. ${ }^{32}$ As we are going to elaborate below, we doubt this inevitable dependance on credits from the World Bank group. The range of autonomy even for immediate action is narrow and tied to international aid, but it is there!

Longer term adjustments are necessary, according to the SAP. In the agricultural sector the persistent necessity for importing staple food (like maize) has to be "reduced" to ensure self-sufficiency. ${ }^{33}$ In order to boost the export volume of major export crops of Tanzania - coffee, cotton, pyrethrum, tea, tobacco, cashew and livestock products - a so called icrop packager for each of these should be developed. Each specific package financially supported by IDA and EEC - comprises policies ranging from inputs, credit, pricing, to processing, transport and marketing improvements. To get an idea of the scope of this programme, one has to realize that it aims to "restore agricultural infrastructure to the standards of the early 1970 s and ensure its maintenance $" .^{34}$

32 SAP, 1982, p. $8 \mathrm{f}$.

33 SAP, 1982, p. $16 \mathrm{ff}$.

34 SAP, 1982, p. 17. 
Table 3

\begin{tabular}{|c|c|c|}
\hline \multicolumn{3}{|c|}{$\begin{array}{l}\text { Exports of Cash Crops } \\
\text { Index: }(1970=100)\end{array}$} \\
\hline & $1975 / 76$ & $1980 / 81$ \\
\hline Cotton & 55,5 & 76,5 \\
\hline Coffee & 111,5 & 135,9 \\
\hline Sisal & 63,2 & 42,5 \\
\hline Tea & 161,7 & 198,7 \\
\hline Cashew & 74,6 & 57,6 \\
\hline Tobacco & 124,5 & 99,2 \\
\hline Pyrethrum & 170,8 & 86,6 \\
\hline
\end{tabular}

Source: Bank of Tanzania, see footnote 19

Similar to the primary sector, the secondary sector should be geared to more efficiency thus enabling it, inter alia, to double export earnings within the SAP period.$^{35}$ In the long run, import-substitution of consumer goods and capital goods is still envisaged in line with the formerly adopted long term Industrialization Programme (1975-95). ${ }^{36}$ Apparently the government tries to keep development strategies constant instead of rapidly changing economic conditions. For the time being, however, priority is given to a rehabilitation programme for existing plants producing basic amenity goods. By that, it was hoped to counteract demoralising effects on the public. However, in 1984 these goods, like cooking oil, soap and even salt, are not available in the regular market, and the resulting demoralising effects among the people are tremendous. For the industrial rehabilitation programme, too, international development aid was expected.

To generate more resources for productive purposes, the expanded public sector could be an useful source. The World Bank group has constantly pressed for cutbacks in this sector. The SAP followed these recommendations only very reluctantly envisaging a "substantial reduction in the development budget", whereas for the recurrent expenditure only a "constraining growth" of up to $12 \%$ was planned. ${ }^{37}$ Here, apparently interests of the governing bureaucratic class have been maintained against external political pressure. Nevertheless, in April 1984 a major reduction of government ministries was carried through.

35 SAP, 1982, p. 25.

36 United Rep. Of Tanzania, "Industrialization Programme in Tanzania", DSM 1979.

37 SAP, 1982 , p. 9 and 11. 
Concluding the comments on the programmatic aspects of the SAP, it should be made clear that there is no intention to change the structure of the economy or society. Rather, the economic crisis predetermines a general line of austerity. In the productive sectors the main goal is the consolidation of already existing national capacities. Pressures of the World Bank group are reconciled with the drive for exports, repeated devaluations in 1979, 1982 and 1983 of the TSh, and promises for more effectiveness.

But doubts remain whether, following this line, enough resources can be made available to reach all three basic objectives of the SAP: import substitution, increase of export production, and improved national supply. Its success will continue to depend, to a great extent, on the flow of international technical and financial aid.

The export-directed impetus of the Programme will only slightly alleviate the dependence on financial aid (see table 5), which has to be measured against growing technical and capital aid costs that will presumably occurr in the course of events.

An alternative strategy would be to concentrate on an integrated and coherent national economy, on a technological level as low as possible, where both the primary and the secondary sector produce inputs for each other locally. ${ }^{38}$ It is true a "replacement of foreign inputs by domestically produced inputs" is also mentioned in the Programme, yet it does not form the core of it. ${ }^{39}$

\section{Table 4}

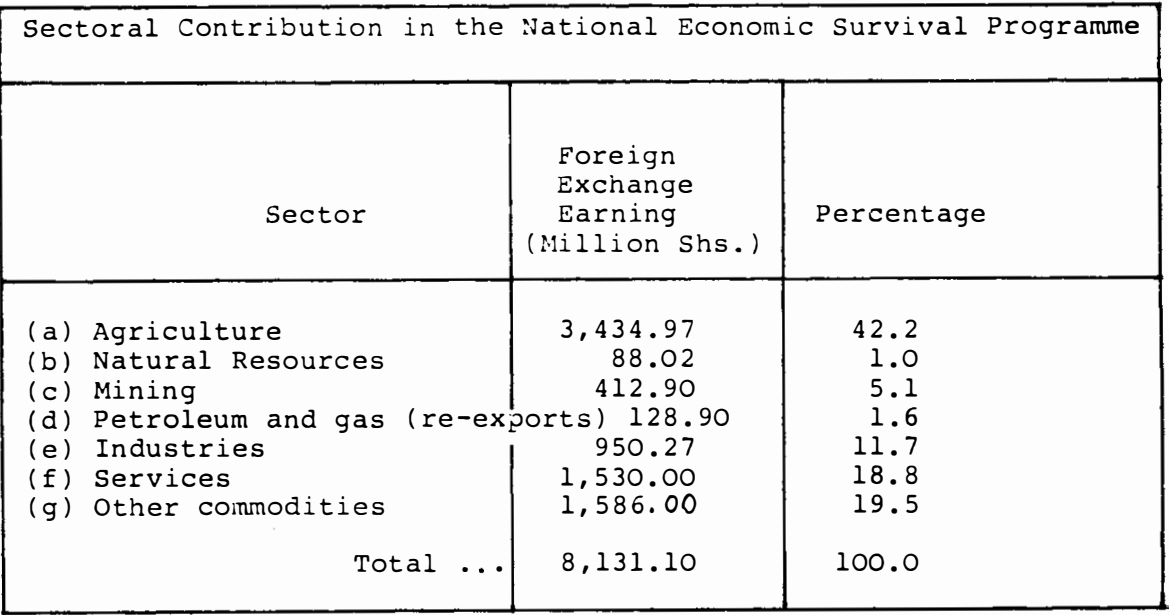

Source: United Rep. of Tanzania, The National Economic Survival Programme, DSM 1982, Annexure 2

38 In this context see $M$. Roemer, G. M. Tidrick, D. Williams, "The range of strategic choice in Tanzanian industry ", Ekistics 259, 1977, p. 346-350.

39 A different path of development has been proposed in: Peter von Mitschke-Collande, "Transfer And Development Of Technology", Institut für Afrika-Kunde, Hamburg 1980. 


\section{Project Design in the Agricultural Sector: A Case in Point}

Since about $90 \%$ of the population live in rural areas and $42 \%$ of the foreign exchange earnings are expected to come from agriculture (see table 4) this sector is worth being looked at more closely. In recent years the main problem of agriculture was a steady retreat of peasants to subsistence. Therefore, the projects are basically directed at reintegrating the peasants into the market economy. The collection of their products and prompt payment by state organisations are to be guaranteed - a vital but, in the past, rarely kept promise in Tanzania. ${ }^{40}$ As an incentive for market production, producer prices shall be raised. The government controlled price system which is not working anymore in practice in present days is to be partly abolished, following pressures of the World Bank group.

In the SAP those measures have been declared "as a matter of highest priority". When announcing the SAP the President affirmed that two thirds of agricultural export earnings would be reinvested in the agricultural sector. The implementation of this policy is pending.

The mode of agricultural production is intended to be furthermore geared to socialism by reintroducing cooperatives (see footnote 13). Cooperatives shall partly take over functions of the various state crop authorities. Ujamaa villages are not mentioned in SAP any more. Alternative technologies like compost manures, animal ploughs and non-motorized wheeled transport are promised to be promoted.

Recently, some Indian-Tanzanian investors were allowed to embark on private large scale modern farming (10 000-40 000 ha). ${ }^{41}$ Whether this form of farming - certainly supported by the Whorld Bank and other political camps - indicates a new trend that will eventually outstrip communal farming with its modest technologies as the dominant mode of agricultural production, remains to be seen.

An important backbone for integrating the hinterland into the market economy (and decentralizing the industry) would be an adequate transport system - a network of railway, trunk roads and feeder roads. Again, the SAP proclaims its expansion by labour-intensive methods with the support of the ILO.42

But the implementation of these projects will inevitably take time; and here our third thesis becomes relevant: a well-working railway system (partly introduced in German colonial time) and good feeder roads to villages are prerequisites for achieving the essentials of Ujamaa socialism: equality, self-reliance and ujamaa villages. For, as long as there is no space-covering transport network, it will be very difficult to integrate villages into the economy, to decentralize secondary production and to realize some sort of self-reliance even in basic consumer goods. E. g. in mid 1984 there is a very serious food shortage in the Dar es Salaam area while at the same time in the southern Naching-

40 SAP, 1982, p. 19.

41 Tanzanian Newspaper: Daily News 9. 9. 1983.

42 SAP, 1982, p. $29 \mathrm{ff}$. 
wea area the maize surpluses are rottening. The infrastructural prerequisites are lacking to cope with this situation.

\section{Conclusion}

Structural adjustment as spelt out by the World Bank would mean the pushing of most efficient productive resources into the world market economy while-neglecting essential remnants of Ujamaa socialism as an nationally desired target. The argument of the World Bank group might be that, taking the state of economic affairs into consideration, Tanzania has no alternative left to improve her balance of payments and force more effectivness. Hence, the main elements of the strategy are:

a) correcting the exchange ratio of the Tanzanian Shilling

b) more export to gain more foreign exchange

c) more effective use of the existing productive stock, better maintenance and fewer overhead costs to increase productivity

d) doing this willy-nilly at the expense of social achievements.

Table 5

\begin{tabular}{|c|c|c|c|c|}
\hline \multicolumn{5}{|c|}{ International Aid to Tanzania } \\
\hline & \multirow[b]{2}{*}{$1981 / 2$} & \multicolumn{3}{|c|}{ The SAP Period } \\
\hline & & $1982 / 3$ & $1983 / 4$ & $1984 / 5$ \\
\hline $\begin{array}{r}\text { 1. Development } \\
\text { Expenditure } \\
\text { (mio TSHs) }\end{array}$ & 5,600 & 4,816 & 5,100 & 5,400 \\
\hline $\begin{array}{l}\text { 2. International } \\
\text { Aid } \\
\text { (mio TSHs) }\end{array}$ & 3,897 & 2,584 & 2,750 & 3,000 \\
\hline 3. 2 in $\%$ of 1 & $70 \%$ & $54 \%$ & $54 \%$ & $56 \%$ \\
\hline
\end{tabular}

Source: SAP, 1982, p. 12 
Tanzania, in the short run urgently in need of finance from IMF and IBRD and additionally under open political pressures from the Western countries, is following this strategy to some extent. The government increased real producer prices by 5 per cent instead of the 40 per cent recommended by the IMF. The Shilling was devaluated by 20 per cent in 1983 failing short of the 60 per cent additionally recommended by IMF. Resi stance to luring demands was upheld in some basic aims of Ujamaa socialism such as nationalization of the economy, avoiding competitive structures with international enterprises in the home market, maintaining the social programme of Ujamaa.

Tanzania has now become aware of the evils of international programmes. "In the longer terms project evaluation, design and choise will be made more sensitive to foreign exchange implications" the SAP sta ted..$^{43}$ However, to which extent Tanzania is able to poker with the World Bank group by sticking to her political credo and thus running the risk to loose credits in the order of 150 million dollars per annum over a period of at least three years? Tanzania earns approximately 500 million dollars a year from her exports. The most necessary imports amount to 1 billion dollars, including 350 million for fuel. Omitting the dwindling aid disbursements of OECD countries, Tanzania would have to cut its imports to 500 million dollars or 150 millions if one subtracts a constant annual oil bill of 350 million which reasonably can't be diminished. ${ }^{44}$

The country could most likely survive putting the cards on the table by limiting its imports to that extent. Certainly, Tanzania would then have to take her commitment to self reliance most seriously, the upper strata of the society would have to give away their share of well being, and the design of development projects would have to be stripped of their reliance on sophisticated technology. The commitment to self-reliance is still part of the SAP but as long as political practice only incrementally follows long term programmes, dependence on foreign aid will subject Tanzania to international pressure. Translated into terms of class struggle in Tanzania the concise focus of the whole debate between Tanzania and the World Bank group would be the devaluation of the Tanzanian Shilling, which would result in a serious increase in the price of staple food of Tanzania, the maize flour.

This would hit the urban poor. Alternatively, dissociation from OECD dependence would menace the gains of the governing few. It is up to the latter do decide.

P. S.: In June 1984 the Tanzanian Government devaluated the Tanzanian Shilling by $25.9 \%$ in order to increase agricultural export production.

43 SAP, 1982, p. 26.

44 Ajit Singh, "The Continuing Crisis of Tanzania Economy: The Political Economy of Alternative Policy Options", Cambridge 1984. 
and linguistic medium of instruction. It is suggested that mastery of science and technology can only be achieved if scientific and technological concepts can be mastered linguistically and thereby, conceptually. Appropriate technology must mean that the recipients are able to grasp it culturally, socially and linguistically. This could be achieved through instruction of basic science based on traditional African technology. Indigenous technological traditions are part of the national culture and, as such, can be verbalized and taught in national languages, i. e., in the linguistic media that determine intellectual conceptualization on the part of the students Integrated science thus comes to mean that scientific concepts are integrated into the entire school syllabus, including language teaching as the means to comprehend scientific concepts linguistically, and also that science, through the aid of the national language, becomes integrated into the cultural and social environment.

\section{Adjustment of Structural Change in Crisis Management Policies of Tanzania}

\section{By Thomas J. Heinrich}

Recent development in Tanzania is but one example of a recurring feature: a developing country in a structural economic crisis exposed to coercion and pressures by aid donor countries and the World Bank group. As a first step the article briefly examines two controversial viewpoints on the causes of the current crisis in Tanzania. Comments presenting the crisis as mainly due to inadequate internal policies in Tanzania are rejected and interpreted as part of the initially mentioned pressures.

The example of Tanzania is most relevant since an autochthonous type of socialist development quite different from the concepts of most developed countries seems to be at stake. However, does the "Tanzanian Model" exist any longer? Some elements of Ujamaa socialism still persist but, under prevailing external constraints, is Tanzania free to defend the basis of "Ujamaa"? The 'Structural Adjustment Programmer of Tanzania (SAP), adopted in 1982 as an intermediate 'for crisis management ' development plan, is taken as an example to approach this issue. For this purpose the remedies' prescribed to the Tanzanian patient by the IMF and the IBRD are summarized and their underlying intentions exposed. Structural adjustment as spelt out by the World Bank group rather means a structural transformation of Tanzanian politics: integration into the world market, less state intervention in the economy. Three theses are put forward to discuss the SAP and the range of options open to Tanzania to maintain a self reliant strategy: the freedom to choose has become very narrow. However, there remains a fairly significant margin for action: exercising influence on the selection and design of development projects: This option is not taken seriously by the Tanzanian government. In her short history, Tanzania was never in an economic position to develop an adequate national infrastructure on which to build the 'Tanzanian Model. Thus, lacking the material foun- 
dations for self-determined development and an adequate development concept, Tanzania muddles through in practice. The main topics of the SAP are presented in the light of these theses.

The SAP led to the recognition that "in the longer term, project evaluation, design and choice will be made more sensitive to foreign exchange implications". Again, if Tanzania is substantially relying on the flow of foreign raid, which sacrifices is Tanzania willing to make to realistically counteract the influences of capitalism? And which strata are prepared to sacrifice? By resisting the pressures of the World Bank group Tanzania eventually would have to cut her imports by half. Then, the upper strata of society would have to give up their share of wellbeing. It is for them to decide on the SAP programme and the future course of political action. 